\title{
Amazing penal institutions and the dwelling circumstances of inmates
}

\author{
Gabriella Ürmösné Dr. Simon \\ National University of Public Service, Faculty of Law enforcement, Hungary
}

\begin{abstract}
Interestingly enough, there are many types of penal institutions all over the world. Most of them are overcrowded, and harsh, humiliating conditions and mandatory rules surround the inmates. Other prisons swim on the sea, or located in picturesque environment over the sea or in one of the Tuscan archipelagos, or located in a dukedom. The rest could represent "five star" penal institutions with all amenities, conveniences, and facilities of tennis court, horse riding or swimming in the sea. Eco prisons also exist with solar panels, bio diesel, recycling, and cultivations. Inmates may live in communities, without the supervision of prison wardens and the lack of window-grates, moreover, they move free. They buy their "own cells", and playing children, stalls, restaurants, hairdresser's, and even a hotel are in the vicinity of their "cells". Other penal institutions accommodate the family members as well, which help children bound their convicted parents, and "disguise" the penal institution in order not to face real prison conditions. Even in the middle of the desert, in military tents inmates are located, and dressed in pink clothes to avoid T-shirt theft. Others are locked in a stone desert or far away in Siberia. Whereas one penal institution can locate only two convicts, others may accommodate ten thousand ones. There is a wide spectrum, which can range from the most lenient penal institutions, to the strictest ones.
\end{abstract}

Key words: penitentiaries, convicts, eco prison, condition of living, resocialization.

\begin{abstract}
About the author
Gabriella Ürmösné Dr. Simon PhD has been teaching technical English for law enforcement officers at the National University of Public Service on the Faculty of Law Enforcement in Budapest for 23 years. She is an assistant professor, and the Head of the Department of Foreign and Technical Languages. Besides her Applied Linguistic PhD studies and researches mainly in psycholinguistics, genderlinguistics, at the ELTE University Faculty of Humanities, she has been indulged in the study of technical English for law enforcement officers and ESP topics, for 23 years. She has published two ESP dictionaries with the lexemes of technical terms, and two course books for law enforcement officers, comprising ESP issues, and she has issued 33 publications on ESP materials as well. Her professional interests involve the improving of ESP topics, and researching on forensic linguistics, genderlinguistics, psycholinguistics, bilingualism with a special emphasis on Greek-Hungarian bilinguals. She has already issued 17 publications on Applied Linguistics, and has 4 law enforcement related scientific studies.
\end{abstract}

- e-mail address: gabo12@citromail.hu or Simon.Gabriella@uni-nke.hu

- postal address: 1225, Budapest, Tenkes u. 7/B. III. /13. Hungary 


\section{Amazing penal institutions and the dwelling circumstances of inmates.}

\section{Introduction}

This paper, is meant to introduce the diverse dwelling circumstances of the convicts, some of which are rather astounding and perplex the reader. In some of them, the inmates are cooped up and live in humiliating conditions, whereas, in the other ones all the amenities are provided for them as if they lived in a 5 star hotel.

In the past, we had dungeons, castles and fortresses for detaining convicts. According to 1978 legislation, the stages of punishment regarding the location of inmates were from maximum security prison, to prison and finally detention centre. If someone is convicted for a short term, or on remand, then they are put in a detention centre. There are special penal institutions for recidivists, the military, juveniles or for those who are considered extremely dangerous to society. In addition, we can distinguish two different methods of imprisonment: "open", and "closed" prisons, and for psychiatric convicts special restricted measures. Penal institutions are state run, but some are financed privately, which means that they maintain their financial existence by selling products produced by the inmates ${ }^{1}$

If someone is convicted and imprisoned, he is entitled to a programme of resocialization, which works towards the prevention of committing further crimes, maintaining his selfesteem, and the improvement of his social responsibility. Generally the judge decides on the serenity of sentence based on the opinion of the forensic psychologist. "The expert work entails high levels of responsibility, and therefore, it requires particular attention and accuracy." 2 Psychologists are not only experts for the forensic phase but also a help during the period of the sentence.

The right to reintegration is a fundamental human right that all people on Earth have. ${ }^{3}$ Life imprisonment takes place in a high security prison. Maximum security prisons have the most secure facilities which typically hold prisoners considered dangerous. The prisoners have individual cells which are on lockdown for 23 hours a day. ${ }^{4}$ They are normally permitted no contact with other inmates and are under constant surveillance via closed-circuit television ${ }^{5}$

Minimum security: Lower-security prisons are often designed with less restrictive features, which permits inmates free movement around the grounds to work or take part in activities during the day. Some countries also have "open" prisons where prisoners are allowed homeleave or part-time employment outside the prison.

\footnotetext{
${ }^{1}$ Lőrinc J-Nagy Börtönügy Magyarországon. Budapest: Büntetés-végrehajtás Országos Parancsnoksága, 1997.

${ }^{2}$ Farkas J, Psychological Assessment of Children by Forensic Experts. Homoki-Nagy M., Hajdú J. (eds.): Ünnepi kötet Zakar András c. egyetemi tanár 70. születésnapjára. Szeged: SZTE-ÁJK, 2017, p. 56.

${ }^{3}$ Kovács I, Egy empirikus kutatás részletei: a prostitúció jelensége, és társadalmi kontrollja napjainkban. Budapest: Dialóg Campus Kiadó, 2019.

${ }^{4}$ Ürmösné S.G, Angol szakmai témakörök a közép-és felsőfokú nyelvvizsgára. Budapest: RTF Kiadó, 2002

${ }^{5}$ See more itemized: Mátyás Sz, Fogvatartotti vélekedés a térfigyelő kamerák használatával kapcsolatban. Belügyi szemle 2019/12
} 
Supplementary punishments comprise prohibition from public affairs, prohibition from their profession, prohibition from driving, confiscation of property, banishment, expulsion, and fines ${ }^{6}$.

The security system in penal institutions is generally, one warder in charge of 20 convicts. He should see them every 20 minutes and is armed with various devices such as a baton, tear gas etc. Between $10 \mathrm{pm}$ and $6 \mathrm{am}$, the warder does not disturb the inmates, only in the case of anything unusual occurring. The security system observes not only the inmates but also the warders, as to whether they are alert enough, their preparedness, tiredness, the situation in the prison, property and documents. Unusual situations happen when crime is committed. We see collective action, suicide attempts, criminal damage, terrorist activity, hunger strikes, barricading of areas, food poisoning, accidents, prison riots, disorder, refusal to be medically examined, the infringement of the penal institution laws such as visiting rights, correspondence, and the possession of illegal property ${ }^{7}$

Prisoners who break the rules of the penal institution may suffer the use of physical punishment such as corporal punishment, handcuffing, use of tear gas, use of electric shocks, batons, dogs, guns, water cannon, pyrotechnic devices, warning shots, chemicals and forced dispersion. These coercive methods should not be used on pregnant women, old men, children and those undergoing medical treatment ${ }^{8}$.

\section{The diverse conditions of prisons worldwide}

Boot camps are part of the correctional and penal system of some countries, but mostly in the United States. They are modelled on military recruit training camps with programs based on shock and grounded in military activity. Boot camp programs are offered to young first-time offenders in place of a prison term. The time served can range from 90 to 180 days, which can replace prison sentences of up to 10 years. They are located mainly in the Western US, Texas and Hong Kong ${ }^{9}$

Have you heard of the largest and the smallest prisons in the world? The smallest prison accommodates one person - a politician - in South Africa on Robben Island. Robben Island in South-Africa was regarded the world's cultural heritage by the UNESCO, and it works as a museum. Many innocent people were convicted here from the XVII. th. century until the XX.th century. Nelson Mandela was located here as well, for 27 years. The biggest prison in the world is located in the Philippines (accommodating 14,000 inmates). On Bastoey Island, we find the most environmental friendly prison ${ }^{10}$. In Austria, Sweden and Norway there are also "luxury 5 star" prisons with all amenities and conveniences. In Leoben penal institution, there are sports facilities with fitness gyms, and internet access. There are language courses, and separate room for couples. The Leoben prison can accommodate 205 convicts. Solely those ones can be placed here, who are deprived of their freedom for 1.5 years.

\footnotetext{
${ }^{6}$ Lőrinc J-Nagy Börtönügy Magyarországon. Budapest: Büntetés-végrehajtás Országos Parancsnoksága, 1997.

${ }^{7}$ Lörinc J-Nagy Börtönügy Magyarországon. Budapest: Büntetés-végrehajtás Országos Parancsnoksága, 1997.

${ }^{8}$ Ürmösné S.G, Angol szakmai témakörök a közép-és felsőfokú nyelvvizsgára. Budapest: RTF Kiadó, 2002.

${ }^{9}$ Ürmösné S. G, Technical English for Officers. Budapest: Dialóg Campus Kiadó, 2018.

${ }^{10}$ (Ruzsonyi, 2014).
} 
Prisons can be located in deserts or jungles. Interestingly enough, there are prisons with heated swimming pools, places on the roof for sunbathing and even a summer vacation for a convicted mother with her child, covered by the local government in Australia ${ }^{11}$

Do you know that in Hungary, the state pays more than 9000 HUF for an inmate daily, which means more than 250,000 HUF a month, and more than 3,000,000 annually?

Prisons are overcrowded, and 2 private prisons have been built in Hungary. Currently, there are approximately 11,500 places for prisoners, however, there are 18,000 inmates. Imagine, how many there would be if suspended sentences weren't used?

Large companies are competing to control private prisons, as it is a thriving business.

One of the toughest prisons in the world is located in the US. The initiator is the rigorous sheriff Joe Arpaio, who is responsible for the prisons in Maricopa Country in Arizona state, which is the fourth largest independent police district. Joe is not a kind person, he is said to have smiled once, about 40 years ago, but he regretted it at once. Neither celebrities, nor youngsters can make him grin.

$\mathrm{He}$ is said to be the toughest sheriff in the country. The legend began in the 90-s, when Arizona state wanted to build a new prison for 4 million dollars. Joe managed to invest only 100,000 dollars to create the new prison. "Tent City" was this new place.

Joe put up military tents in the middle of the desert, and put in 2,000 convicts. It is 50 celsius in the desert, and according to him, what is good for soldiers, will be good for criminals too ${ }^{12}$

Convicts may only move around the yard in chains, and women are not exempt. According to him, the same rights should be given to both sexes. The lights are only on when someone rides the bike which generates an electric current. Inmates used to steal black T-shirts and traded them, so he decided to give them pink ones instead. Since then, T-shirt theft has ceased. Arpaio prohibited coffee, cigarettes and men's magazines. Although the daily catering for one inmate costs 60 cents, he spends 1 dollar 10 cents on the police dogs. Dogs have their own mattresses and blankets, which are laundered by the inmates. If someone behaves badly, he puts them on bread and water as a punishment. Uncle Joe does not believe in rehabilitation, he prefers deterrence.

He used to place 4 webcams in a detention centre where 300 suspects were located on remand. Because of the internet everybody could keep tab each day on the convicts' lives. People could also watch fist fights and rapes live in women's cells. On the first day 3 million people were watching the website. According to the sheriff, live broadcast was effective in deterring any inmate who had previously had contact with a prostitute, because he now has an opportunity to send a message, via the camera, to his wife: "Hi darling, I' $\mathrm{m}$ here, don 't worry, I 'll be a bit late."

\footnotetext{
11 (Ruzsonyi, 2014).

12 Ürmösné S. G, Technical English for Officers. Budapest: Dialóg Campus Kiadó, 2018.
} 
At the entrance of the camp there is a sign: "VACANCY". Joe's motto is simple: "If you don't commit a crime, you won't be imprisoned."

Joe is always re-elected by a weapon loving Arizona State and when he goes on campaigns he goes around the county in a tank. He imprisons even celebrities like Mike Tyson, who also had to wear pink socks.

Russian prisons are notoriously tough, but there's one that's even harder than the rest. Called Black Dolphin, this high-security prison on the Kazakhstan border houses 700 of the country's most brutal criminals, including serial killers, cannibals, paedophiles, maniacs and Chechen terrorists. It is named after the dolphin sculpture, created by the inmates themselves, which sits on the grass at the front of the prison reception. Combined, the inmates have killed about 3,500 people. That's an average of five murders per inmate.

Nikolayev killed a man during a drunken fight, then dragged him into his bathroom and chopped him up. He told how he accidentally killed a man during a drunken brawl before deciding to try the taste of his flesh. "I cut off his head, arms legs and all of a sudden something kind of struck me and I thought I would try him. "I cut off a piece of meat of his thigh and boiled it. I tried it and didn't like it, so I chopped it up and fried it in a frying pan. "I gave some meat to one of my friends, he took it home and gave it to his wife. She made dumplings with it, she had some herself and fed it to her children. "I said it was kangaroo, we don't have kangaroos around here. They didn't know what it was."

Inmate Nikolai Astankov was jailed for killing an entire family then burning their bodies in a forest. Black Dolphin prisoners are kept under 24-hour video surveillance, and there are light and motion detectors as well. The cells are set back behind three sets of steel doors. Inmates live in a 'cell within a cell.' Two inmates share one 50 square foot cell. Guards make rounds every 15 minutes. When inmates leave their cells, they're forced to walk bent at the waist. An inmate is frogmarched through the jail with his head facing the floor. The tactic is used to stop prisoners learning the layout of their surroundings. This technique is believed to be unique to Black Dolphin. Inmates are blindfolded when they walk outside. These two techniques ensure that prisoners don't have a good understanding of the prison layout. Every inmate is kept isolated inside a single cell. They are taken out of their cell for only 90 minutes per day which is spent inside a barren concrete exercise yard. They are fed soup and bread four times directly to their cells. The prison has attracted controversy in recent years after campaigners compared it to the infamous Soviet gulags. Inmates have been known to self-mutilate in protest at their living conditions.

Piedras Gordas penitentiary, on the outskirts of Lima, sits at an altitude of 4,800 meters $(15,737$ feet) in a remote area of southern Peru where temperatures can plunge from $9 \mathrm{C}$ (48 F) in the daytime to minus $20 \mathrm{C}$ (minus $4 \mathrm{~F}$ ) at night. It is situated in the stone desert of Peru, and dug into $20 \mathrm{~m}$ deep, so that the inmates cannot see anything if they are let to walk. $10 \mathrm{~m}$ tall concrete wall surrounds them with barbed wire. The foreign drug couriers are supervised by 500 prison wardens. The courier caught in the airport, is transferred to the Driandro which is similar to detention centres, where the circumstances are inhuman. According to the Hungarian drug couriers, they have to sleep on the ground, parcels are not handled, and phone 
calls must not be made. Generally, inmates are located there for 7-15 days during which the investigation and the interrogation are held, and meanwhile, their money, wrist watch and jewels are taken or stolen. Very small amount of meal is provided, and only 2 glasses of water are given for the inmates. Afterwards, at the public prosecutor's office they are not given any meal or drink for 3 days, and they have to sleep on the ground or stairs without any blanket. When they arrive at the Piedras Gordas prison, they face the violence of the other inmates such as: beating, rape, setting the blanket on fire and scalding. No wonder that attempted suicide, suicide, hanging, and cutting veins frequently happen. Inmates can be "bathed by the others in a big "tub" where the others wash their face, teeth, and plates. The premises designed for 63 inmates, locate approximately 350. Most of the convicts obtain knives, weapons, and drugs. If convicts want to work, they have to pay for the facility. No one knows when they are released.

Computer programming course is getting more popular among the inmates of the San Quentin state prison in California state. The peculiarity of the tuition is, that it is proceeded via video conference. The project was created by Chris Redlitz and Beverly Parenti in the framework of a non- profit organization called "The Last Mile". The initiation was launched hard, and the two founders working in the high-tech industry struggled much. The basic difficulty was that the convicts must not use the internet. The creators therefore had to develop such a programme, which is apt for tuition without the usage of the internet. Despite the distance, video conference makes it possible to create a systematic tuition and acquisition. The other problem was that the half of the candidates have never used computer before. Participants are expected to be attentive and sober, and those who do not manifest due attention and discipline, are expelled immediately ${ }^{13}$ (Király, 2015). Although the prison is located in a beautiful environment, right on the Californian beach, the San Quentin State Prison is one of the most overcrowded prisons, where thousands of inmates are located. There has been also a Death Row in the penal institution since 1996, where death sentence is executed by lethal injection.

In the province of Guangdong penal institution, internet forum was created for the relatives of the inmates. Relatives are permitted to inquire directly from the staff of the penal institution about the incarcerated family members. The chat is faster and has personal nature, moreover, it is cheaper than telephone conversation. The forum was searched by thousand users, and 170 messages and comments were left by the one month probe.

The Norwegian Bastoey penal institution was the first, who created the first eco prison in the world. The prison island was established in 1982, and was regarded a luxurious prison. In fact, it does not have a traditional prison environment, yet, the view of the Scandinavian execution of sentence is highlighted there, which reflects that inmates have to be treated as humans. The institution does not have walls, gates and security systems, moreover the convicts can move free. The prison was created as being a local community with its approximately 80 buildings and places of amusement, agricultural fields and a forest ${ }^{14}$. The

\footnotetext{
${ }^{13}$ Király.K, Hírek a börtökvilágból. Börtönügyi Szemle. Budapest: 2015/2

${ }^{14}$ Juhász. Zs, Új színfolt a börtönök palettáján: A “zöld börtön”. Börtönügyi Szemle. Budapest: 2017/2
} 
inmates grab the environmental opportunity and angle, ride a bike, swim, jog or walk on the island. No wonder, that the institution is said to be a "summer camp" or a "sports club". The only danger of this institution is, that potential convicts may claim: "I will steal anything in order to have access into the institution." No wonder, since the lifestyle in the 5 star prison resembles to a "summer camp" with its tennis court, horse riding facility, and even swimming in the sea. The prison community deserved the eco prison designation for the reason why there is organic farming on the fields, chemicals like pesticide are not allowed to use, the waste is recycled, renewable energy resource is used, and they minimalize the emission of CO2. The few cars on the island use bio diesel, what's more, horses are used for transportation, solar panels are used, and in every year planting of trees is carried out. The bio vegetables fostered on the fields and in the green house, are partially used for themselves and for sale as well. Animals, such as sheep and cattle are used for cultivation and catering the prison. It is an essential factor, that the inmates have to take care of the animal husbandry, and they also have to cultivate the land ${ }^{15}$. The prison island's awareness of the environment may promote the protection and the respect of nature amongst the convicts. Similarly to the Bastoey prison, the Cedar Creek penal institution in Washington state is worth mentioning for the reason why it endeavours to self-preservation, and as a result of this, the institution can save 17.000 dollars annually by consuming the vegetables fostered by the inmates. Besides this, the establishment located in the forest, recycle the scran, moreover the compost is used both in the garden and in the green house, by which a further 3000 dollars can be saved. The male convicts' task is to take care of the beehives, and as a consequence, honey is produced by the prisoners, who bake cakes, and create ointment and lip balm from honey. The "green execution of sentence" does not only provide stock-raising and cultivations for the prisoners, but eco therapy as well, which covers physical, psychical and nature based methods too. These programmes teach the convicts how to take care of the environment and the animals, moreover, they contribute to such abilities like collaboration, responsibility, provision and empathy. "Green programmes", compared to other rehabilitative methods, turned out to influence the risk-taking, decision-making and the psychosocial functions of the inmates significantly. Facilities, provided by the nature, influence the cognitive functions in a positive way, may reduce stress and hypertension. Green Team-programme for instance, provides such a vocational training, which comprises garden therapy, reading and writing ability, the improvement of life-coaching, and a 9-12 month long paid traineeship of cultivating gardens in the town ${ }^{16}$.

Convicts can buy cells for themselves in the San Pedro prison in Bolivia. This prison is the biggest penal institution in La Paz with its 1500 convicts. Entering the penal institution, the diversity between an average prison and this institution strikes everyone, since there are playing children, stalls, restaurants, hairdresser's, and even a hotel. There aren't any guards, uniforms, or even window grates. In exchange, everyone has to pay 1000-1500 dollars,

\footnotetext{
${ }^{15}$ Juhász. Zs, Új színfolt a börtönök palettáján: A “zöld börtön”. Börtönügyi Szemle. Budapest: 2017/2

${ }^{16}$ Juhász. Zs, Új színfolt a börtönök palettáján: A “zöld börtön”. Börtönügyi Szemle. Budapest: $2017 / 2$
} 
regarding the length of the sentence and the quality of the cell. Tourists used to be allowed to enter, but it was prohibited, since too many visitors came for buying cocaine ${ }^{17}$

33 million people have seen the dancing convicts of the Cebu prison in the Philippines on youtube. The idea came from the scene of the film called "The Shawshank Redemption", where music had a great impression on the convicts. Since the famous video, many donation shows have been held by the convicts, and photos could be made after the performance, and T-shirts could be bought for souvenirs.

Russian prisons are famous for their overcrowded conditions. The Kreszt penal institution in Saint Petersburg is said to be one of the most overcrowded prisons in world. The capacity is virtually 3000 members, but the real number is never less than 10.000 . Every inmate has $4 \mathrm{~m} 2$ own space, and 15 minute long shower per week ${ }^{18}$

Guernsey is a little island between Europe and Great Britain, where the smallest prison in the world called Sark can be found. The island has 600 inhabitants, but in its prison, only 2 inmates can be located. It was built in 1856, and it still works.

The United States Penitentiary Administrative Maximum Facility (ADX) in Colorado was opened in 1994, and said to be the "king" of penal institutions and the safest prison in the world. The inmates spend 23 hours in a $2 \times 4$ meter solitary cell. The tables and chairs made of concrete, cannot be moved, and convicts must not leave the cell even for having lunch. The windows are $10 \mathrm{~cm}$ wide, and placed in order to mislead the convicts not knowing where they are located. No wonder, that many inmates become insane during their incarceration ${ }^{19}$.

Aranjuez is located $40 \mathrm{kms}$ south of Madrid, which is regarded a family prison. It has 36 cells for families. There are Disney characters on walls, and there is a playground too. The objective of such environment is, to help children bound their convicted parents, and "disguise" the penal institution in order not to face real prison conditions, what's more, it contributes to amend their way of lives as caring parents in the role of a mother and a father.

In Cereso Chetumal penal institution in Mexico, conflicts are solved by box matches. The convicts did not commit any violent action against each other in the last 10 years because, should any problem crop up between two inmates, they get boxing gloves, and the dispute will be over within two rounds. Many inmates wouldn't like to leave the institution, because the catering is good, the leisure time activities are also, not to mention the VIP cells as well.

The Alcatraz penal institution in California is said to be the most famous prison in the world. The Alcatraz island - or in other name the Rock - was originally a light tower. Later, it became a fortress, and a military prison, and from 1934 a penal institution. Its most popular convict was Al Capone. In 1963, the prison was closed due to the decision of Robert Kennedy. Since then, it has become a touristic attraction for visitors. According to the operators, no one managed to abscond from the prison, during its 29 year existence.

The Maison d'Arrét prison in Monaco is one of the trendiest penal institutions in the world, because it is located in the popular dukedom of one of the most posh environment. The prison

\footnotetext{
${ }^{17}$ Ürmösné S. G, Technical English for Officers. Budapest: Dialóg Campus Kiadó, 2018.

${ }^{18}$ Ürmösné S. G, Technical English for Officers. Budapest: Dialóg Campus Kiadó, 2018.

${ }^{19}$ Ürmösné S. G, Technical English for Officers. Budapest: Dialóg Campus Kiadó, 2018.
} 
is over the sea in a beautiful environment. Its capacity is only 80 members. In fact, there is no need for bigger prison, since the number of criminals in Monaco is the least in Europe.

Gorgona prison in Italy is one of the members of Tuscan archipelagos, where criminals have been located since 1869. Generally, the dream of the inmates is, to spend the sentence in such a paradisiac environment. Prisoners are allowed to spend much time in open air, they can earn money which they get for their work in the hope of restart. Convicts may work in vineyards, cheese factory and on farmland.

The Halden penal institution in Norway can locate 252 inmates and it was opened in 2010. In its first years, this penal institution was regarded the most human prison. The building complex was designed like a village. Every inmate has an own room with TV set, lavatory and a separate bathroom. There is no window-grating, since they trust the inmates. There is a fitness room, sports hall, and a football pitch in the prison.

In Switzerland, Sennhof, the IIha Grande prison was initially a house, then it worked as a workshop, which was built in a picturesque environment in 1603. In 1817, it was converted a penal institution. Its final image was created in 1934. In this penal institution, 73 convicts can be placed.

The Dutch Overloon A De Maasberg is a juvenile correctional institution, which enables the youngsters to move free between the cells and the workplace. They try to promote resocialization by permitting free movements.

The Heidering Correctional Facility located in Grossbeeren Germany, was built in 2013. The overall cost of the state-of the art building was 120 million euros. The capacity of the institution is only 650 members. The building was designed to let light in everywhere. A 260 $\mathrm{m}$ recreation yard and diverse sports grounds belong to the institution, where the convicts can let off steam.

Offenders are punished in a special way, in one of the American towns. Troublemakers may choose between either going to prison, or to a church. Bay Minette in Alabama chose an interesting way of amending offenders' way of lives in a cost-effective way. Instead of bars, they are offered to go to church for a year, in order to redeem their offence. On every Sunday, they have to participate on Church service, which is supervised by the probation officer and the clergyman. The offenders choose which church they would like to go, and they have to keep contact with the local clergyman and the police as well. If they successfully absolve the yearlong penance, then all charges are dropped. The authorities and the Church hope, that the offenders will amend their way of lives, and may be converted by going regularly to church. According to the sheriff of Bay Minette town, Mike Rowland, this programme may change people's lives, but not only theirs, but their family members' as well. 56 churches have already joined the programme.

In 1992, 111 unarmed rioting convicts were killed by policemen in the Brazilian prison in Sao Paulo called Carandiru. The commander, who was responsible for the bloodshed, was sentenced for 632 years, and acquitted subsequently. The prison massacre was an abnormal 
case though, most Brazilian penal institutions are hot, dark, dirty, violent, overcrowded and infectious. Conflict which erupted between two convicts, led to a prison riot on $2^{\text {nd }}$ of October, 1992 in Carandiru, where the convicts assumed control over the $9^{\text {th }}$ block. Policemen were shooting everyone by shotgun, machine gun, without question, despite the fact, that not everybody joined the rioters. Afterwards, everybody had to strip naked, and had to run to the yard. Those who were slow, or slipped, were shot. They were obliged to run round, whilst they were beaten by truncheon, or the others were bitten by police dogs. The BBC made a report in 1998 about the Carandiru prison which was operating at that time, and revealed, that more than 7000 inmates were guarded, twice as much as its capacity, and supervised by 1000 prison wardens, working in 4 shifts. According to estimations, 1300 inmates lost their lives due to violence. Carandiru was finally exploded in 2002, after moving all the convicts. Prisoners rioting simultaneously in 27 penal institutions in Sao Paulo state, and taking hostages visitors, gave the boost for ceasing Carandiru. In its heyday, more than 8000 convicts were guarded here, and altogether, 170.000 convicts were there.

There were some Brazilian prisons, where sunlight could not filter through, or there were only some little windows at the end of the long corridor. There were some solitary cells, where there was darkness day and night. Due to overcrowded conditions, epidemics spread all of a sudden, and the patients cannot be separated at all, and there are only few doctors. Patients with meningitis, AIDS, tuberculosis, and epilepsy are together with healthy inmates, and solely those who have advanced disease may get medical assistance and infirmary. Presumably, AIDS and TBC are in leading position regarding death rates in Brazilian prisons. Stripping, forcing on knees, beaten by baseball bat, strangulation, torture, escape, taking hostages, disturbance and rape are well-known in these prisons. There were some prison institutions, where females and juveniles were locked among males, and there were cells for 35 convicts, and 208 females were placed there, or, where the capacity was for 104 convicts, 900 males were accommodated. In the Amazonas prison, there was such a cell, where a hole on the ground was equivalent to the toilet. In other prisons, the rotten leftovers, and waste were on the corridors or even in cells, which infect both prison wardens and the inmates as well.

The Vernon C. Bain prison in New York, does not stand, but swims, because, there wasn't enough place on land. Practically, it is an enormous scow, which guards 800 medium and maximum security convicts. Since it isn't fixed to the shore, therefore as a ship, the rules of the coast-guards refer to it. 3 member crew is always on the deck including the first officer, the engineer and the machinist, which enhances the expenditures of the maintenance by 650.000 dollars annually. On the deck of the A Vernon C. Bain, there is everything that is on the ground: huge kitchen, library, fitness room and a basketball court too.

\section{Conclusion}

As we could see, there are many types of penal institutions worldwide, some of which are "five star" ones with all amenities, others have humiliating conditions and harsh, severe conditions, whilst eco prisons, and penal institutions without prison wardens, bars and window-grates also exist. As a consequence, there is a wide range of spectrum, concerning the 
environment and the circumstances of penal institutions worldwide. Anyone might linger on which types of the above mentioned prisons are the most humane, considering the rights of inmates and providing appropriate conditions. The objective of this paper was to introduce the diverse circumstances and spectrums of prison conditions, by not judging, which one is more effective from the point of view of both the society and the convicts.

\section{References}

Farkas J, Psychological Assessment of Children by Forensic Experts. HomokiNagy M., Hajdú J. (eds.): Ünnepi kötet Zakar András c. egyetemi tanár 70. születésnapjára. Szeged: SZTE-ÁJK, 2017, p. 56.

Juhász Zs, Új színfolt a börtönök palettáján: A “zöld börtön”. Budapest: Börtönügyi Szemle. 2017/2.

Király K, Hírek a börtökvilágból. Budapest: Börtönügyi Szemle. 2015/2

Kovács I, Egy empirikus kutatás részletei: a prostitúció jelensége, és társadalmi kontrollja napjainkban. Budapest: Dialóg Campus Kiadó, 2019.

Lőrinc J- Nagy F, Börtönügy Magyarországon. Budapest: Büntetés-végrehajtás Országos Parancsnoksága. 1997.

Mátyás Sz, Fogvatartotti vélekedés a térfigyelő kamerák használatával kapcsolatban. Budapest: Belügyi szemle 2019/12.

Ruzsonyi P, Presentation on Researcher's night, 2014

Ürmösné S.G, Angol szakmai témakörök a közép-és felsőfokú nyelvvizsgára. Budapest: RTF Kiadó, 2002.

Ürmösné S.G, Technical English for Officers. Budapest: Dialóg Campus Kiadó, 2018.

http://www.erdekesvilag.hu/kulonleges-bortonok-vilagszerte/

http://www.origo.hu/nagyvilag/20130419-elobb-lottek-nem-is-kerdeztekcarandiru-es-a-brazil.html

https://hir.ma/kulfold/szines-hirek/kulonleges-bortonok-a-vilag-nehany$\underline{\text { szegleterol/474151 }}$ 
https://netextra.hu/az-alcatraz-10-legveszelyesebb-foglya/

http://mindennapi.hu/cikk/eletmod/a-bunozok-valaszthatnak-a-templom-es-aborton-kozt/2011-09-25/7773

http://www.businessinsider.com/inside-russias-black-dolphin-prison-20167/\#exercise-consisting-of-pacing-back-and-forth-takes-place-in-another-cellthere-is-no-prison-yard-14

https://www.thesun.co.uk/news/5017746/inside-russias-most-brutal-prisondubbed-the-black-dolphin-where-the-countrys-worst-terrorists-paedos-andcannibals-are-held/

http://www.foxnews.com/world/2014/09/04/joran-van-der-sloot-records-phonevideo-his-life-in-peruvian-maximum-security.html

http://rtl.hu/rtlklub/fokuszplusz/videok/340935

http://toochee.reblog.hu/borton-a-viz-felett

http://www.baptistasegely.hu/hirek/kulfold/elveszett-eletek-peruban-avagy-abunhodes-stacioi 
